\title{
TAXONOMY AND DISTRIBUTION OF THE SOUTH AMERICAN TOAD BUFO POEPPIGII TSCHUDI, 1845 (AMPHIBIA, ANURA, BUFONIDAE)
}

\author{
I. De la Riva *
}

\begin{abstract}
The taxonomic status of the Andean toad Bufo poeppigii has been controversial since its description by Tschudi in the 19th Century, because of the similar appearance of the species with respect to Bufo marinus, and the fact that both species may occur together in some localities at the foot of the Andes. Bufo poeppigii is a valid species occurring on the Amazonian slopes of the Andes, at least from central Bolivia to northern Peru. It differs from B. marinus mainly by a less marked sexual dimorphism in size, smaller size, rugose skin always present in males, distribution of nuptial excrescences, and some features of the parotoid glands. The variability of B. marinus encompasses that of $B$. poeppigii; thus, in some cases it is difficult to identify some specimens.
\end{abstract}

Key words: Anura, Bufonidae, Bufo poeppigii, B. marinus, B. arenarum, taxonomy, distribution, South America

\section{RESUMEN}

Taxonomía y distribución del sapo sudamericano Bufo poeppigii Tschudi (Amphibia: Anura: Bufonidae)

La posición taxonómica del sapo andino Bufo poeppigii ha sido objeto de controversia desde su descripción por Tschudi en el siglo XIX. Ello se ha debido a su parecido con Bufo marinus y a que ambas especies pueden encontrarse juntas en algunas localidades del piedemonte andino. No obstante, Bufo poeppigii es una especie válida que habita en las laderas amazónicas andinas, al menos desde el centro de Bolivia hasta el norte de Perú. Difiere de B. marinus por tener dimorfismo sexual en tamaño menos marcado, menor talla, piel siempre rugosa en los machos, la distribución de las callosidades nupciales y algunos rasgos de las glándulas parotoides. La variabilidad de $B$. marinus abarca la de $B$. poeppigii, de modo que a veces es difícil identificar ciertos ejemplares. Palabras clave: Anura, Bufonidae, Bufo poeppigii, B. marinus, B. arenarum, taxonomía, distribución, Sudamérica

\section{Introduction}

Among the rich anuran fauna of the Andes are several species groups within the toad genus, Bufo. Whereas the Bufo veraguensis and Bufo spinulosus groups are endemic to the Andes, other, primarily lowland groups have some representatives on the Andean slopes and/or at the foot of the mountains (Duellman \& Schulte, 1992). Examples of these groups are the B. "margaritifer" complex (Hass et al., 1995) and the B. marinus group. Among members of the B. marinus group, several taxa have been

* Departamento de Biodiversidad y Biología Evolutiva, Museo Nacional de Ciencias Naturales, CSIC. C/ José Gutiérrez Abascal 2, 28006 Madrid, Spain 
reported or described explicitly from the Andean region of Peru and Bolivia. These are, by chronological order of description: 1) Bufo marinus (Linnaeus, 1758) [type locality: "America"; restricted by Müller \& Hellmich (1936) to Surinam], a widespread species in the Neotropics (it has also been introduced elsewhere) that reaches the Andean slopes and foothills from Venezuela to Bolivia (De la Riva et al., 1996, 2000); 2) Bufo poeppigii Tschudi, 1845, described from the Andes of Peru (type locality: "Montañas de Monobamba"), and reported from the eastern Andean slopes of Ecuador, Peru and Bolivia (Frost, 1985); the taxonomic status of this species has been in a state of flux since its description, being often considered as a subspecies of $B$. marinus; 3 ) Bufo arenarum Hensel, 1867 (type locality: Río Grande do Sul, Brazil), a species occurring primarily in the lowlands of southern South America, but also in the Andes of Central Bolivia up to $2600 \mathrm{~m}$ (Frost, 1985); B. arenarum and B. poeppigii are superficially similar in appearance; 4) Bufo marinus andinensis Melin, 1941 (type locality: Roque, $35 \mathrm{~km} \mathrm{SE}$ Moyobamba, Departament of San Martín, Peru), unanimously considered a synonym of $B$. marinus; 5 ) Bufo paracnemis A. Lutz, 1925 (type locality: Belo Horizonte, Minas Gerais, Brazil), a species closely related to $B$. marinus and known from Argentina, southeastern and central Brazil, Paraguay, Uruguay, and Bolivia, that reaches the foot of the Andes in some parts of Bolivia (De la Riva, 1990); B. paracnemis does not present any problem regarding its identification or taxonomic status; and 6) Bufo gallardoi Carrizo, 1992, described from Andean Argentina (type locality: Monolito, 1700 m, Calilegua, Jujuy, Argentina); the species-group allocation and putative distribution of $B$. gallardo i in Bolivia are doubtful (Harvey, 1997; De la Riva et al., 2000) and beyond the scope of this paper.

Intensive field work in the Andean region of Bolivia led me to recognize that $B$. marinus and $B$. poeppigii are distinct species that are sympatric at some localities on the lower slopes. This impression was reinforced by further examination of many Andean specimens of Bufo in museum collections (Appendix I). The purpose of this paper is to discuss on the specific status of $B$. poeppigii and provide remarks on the diagnosis, distribution, and ecology of the species.

\section{Taxonomic history of Bufo poeppigii}

Tschudi (1845) described Bufo molitor and $B$. poeppigii, respectively from "Peru" and "Montañas de Monobamba" [a locality in the departament of Junín, Peru (11 ${ }^{\circ} 25^{\prime} \mathrm{S}, 75^{\circ} 11^{\prime} \mathrm{W}$, ca. $\left.\left.2000 \mathrm{~m}\right)\right]$. Roux (1907) considered both names as synonyms of $B$. marinus Linnaeus, but Nieden (1923) resurrected $B$. poeppigii as a valid species and considered $B$. molitor to be a junior synonym; however, all subsequent authors have placed $B$. molitor in the synonymy of $B$. marinus. Since then, the taxonomic status of $B$. poeppigii has been changing continuously. Most authors have not provided justification on which their placement of $B$. poeppigii, either as a full species or as a subspecies of $B$. mari$n u s$, was based. Bufo poeppigii has more frequently been considered as a valid species (e.g., Vellard, 1955; Blair, 1972; Bogart, 1972; Cei, 1972; Guttman, 1972; Duellman \& Toft, 1979; Zug \& Zug, 1979; Duellman, 1979; Harding, 1983; Frost, 1985 ) than as a synonym of B. marinus (e.g., Mertens, 1952; Vellard, 1959; Cei, 1958; Bertini \& Cei, 1961; Gorham, 1974). The only comprehensive attempt to elucidate the taxonomic status of $B$. poeppigii was made by Henle (1985). He stated that $B$. marinus and B. poeppigii "as well as different intermediate forms were completely mixed in Peruvian populations with no ecological differences between them," and recognized the subspecies B. marinus poeppigii. Although this criterion was followed by several authors (e.g., De la Riva, 1990; Henle, 1992; Duellman, 1993) most continued recognizing $B$. poeppigii as a full species (e.g., Cadle \& Patton, 1988; Almendariz, 1991; Emmons, 1991; Duellman \& Schulte, 1992; Rodríguez et al., 1993; Hass et al., 1995; Morales, 1995; De la Riva et al., 1996; Ruiz-Carranza et al., 1996; Glaw et al., 1998; Duellman, 1999; De la Riva et al., 2000; Köhler, 2000).

\section{Taxonomic status and diagnosis of Bufo poeppigii}

I examined the holotype of B. poeppigii, MHNN 90.77, and topotypic material representing this taxon from the mountains of Monobamba, Peru. The specimens from San Ramón and Yaupi (and, to a minor extent, those from Tsioventini and Río Perene; see Appendix I) may be considered as topotypic, inasmuch as these localities are in the mountains around Monobamba. Henle (1985) assumed that the type locality of $B$. poeppigii is Moyobamba, Department of San Martín, Peru. This assumption is unwarranted, because there is no reason to suppose a misspelling of the type locality in Tschudi's description. Furthermore, there are at least three different Peruvian localities called 
Moyobamba, each one situated in a different department (see Stephens \& Traylor, 1983).

Because the holotype of $B$. poeppigii is a juvenile or small subadult $(\mathrm{SVL}=52.9 \mathrm{~mm})$, faded, decalcified, and softened, it is impossible to assess with certainty whether it actually represents what has been commonly recognized as $B$. poeppigii (or B. marinus poeppigii) or is a juvenile of $B$. marinus. To the best of my knowledge, no specimens identified as $B$. marinus have been collected at high elevations in the area of the type locality of $B$. poeppigii. Thus, I conclude that $B$. poeppigii is the available name for this different taxon. This is the only possible argument to assume that the holotype of $B$. poeppigii is the name-bearing type of the species closely related to, but different from $B$. marinus occurring in the eastern slopes of the Andes. In order to determine that no other described taxa correspond to what we recognize today as $B$. poeppigii, I also examined the two syntypes of $B$. molitor (MHNN 90.87) and the two syntypes of $B$. marinus andinensis Melin (NHMG 457), from Roque, $35 \mathrm{~km}$ SE Moyobamba, Departamento San Martín, Peru. I agree with former authors in considering both nominal taxa as junior synonyms of $B$. marinus.

Based on the poor condition of the holotype of B. poeppigii, it is not surprising that Henle (1985), after comparing it with the syntypes of $B$. molitor and with a large sample of $B$. marinus from other regions (including Middle America, West Indies, South America, Australia, and Fiji), concluded that $B$. poeppigii and B. marinus are conspecific.

In many cases it is not easy to distinguish $B$. poeppigii from $B$. marinus (Figs. 1-3). The latter is quite variable in size, skin texture, development and shape of the parotoid glands, and dorsal and ventral patterns (personal observation; see also Zug \& Zug, 1979), whereas B. poeppigii shows little variation throughout its geographical range. Keeping this in mind, the main differences between $B$. poeppigii and $B$. marinus are (condition in $B$. marinus in parentheses): (1) males always with rugose skin, with many tubercles of similar size, each covered by many keratinized spicules (Fig. 2); a higher number of tubercles in the sacral region, where the tubercles are more closely spaced (texture of the skin variable in amount, size, and disposition of tubercles); (2) parotoids subtriangular, flattened, their borders poorly defined, never hypertrophied (parotoids subtriangular, protuberant, often hypertrophied; Fig. 3); (3) males bearing extensive nuptial excrescences on Fingers I, II, and III (nuptial excrescences normally present on
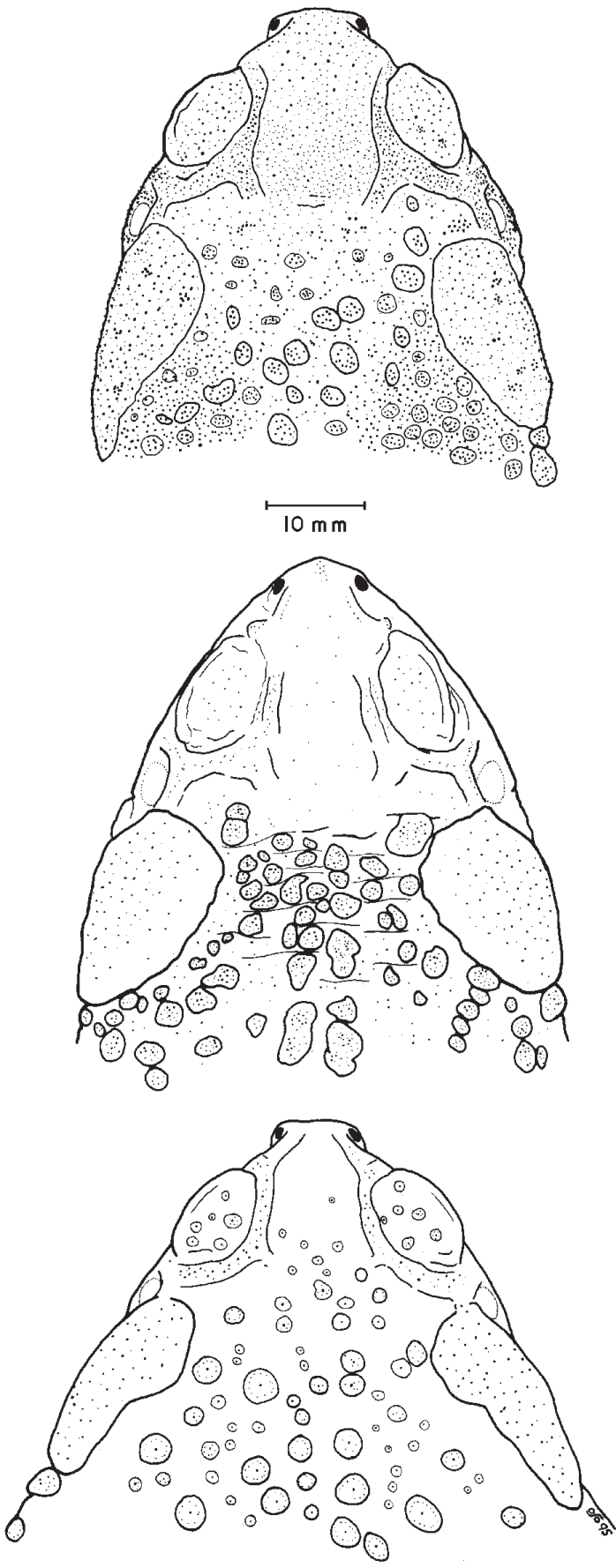

Fig. 1.- From top to bottom, heads and parotoid glands of $B$. poeppigii (KU 183227), B. marinus (KU 196665), and B. arenarum (KU 183186).

Fig. 1.- Cabezas y glándulas parotoides de B. poeppigii (KU 183227), B. marinus (KU 196665) у B. arenarum (KU 183186) (de arriba a abajo). 


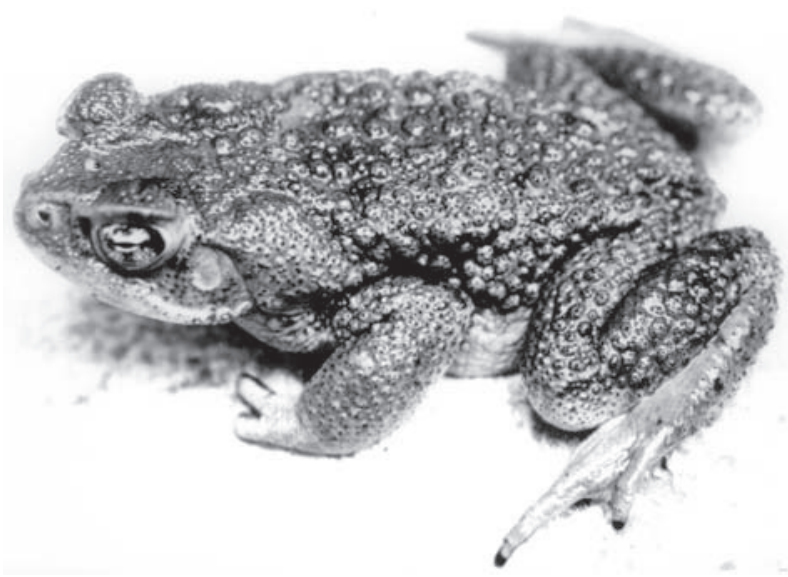

Fig. 2.- Bufo poeppigii (KU 183237) from Coroico, Bolivia (KU slide \# 6440).

Fig. 3.- Bufo poeppigii (KU 183237) de Coroico, Bolivia (KU diapositiva \# 6440).

Finger I only and, if present on the other fingers, poorly developed); (4) males with dorsum brown or tan, usually lacking pattern; females often having small dark, not sharply defined blotches; immature individuals mostly gray with small dark blotches surrounding the dorsal tubercles (dorsum brown or tan, usually with large black, well defined blotches, especially in females and immature individuals); (5) venter always uniformly pale (often marbled with gray).

The range of variation in $B$. marinus across its entire range encompasses that of $B$. poeppigii. Although distinguishing the two species should not be problematic when large samples are considered, at localities where both species occur it may be difficult to assign a particular specimen to one or the other species. I tried unsuccessfully to find any ratio in body proportions to distinguish the two species properly; it seems that conclusive discrimination based on measurements is not possible. One of the most consistent differences between the two species is overall size and degree of sexual dimorphism in size and skin texture, as pointed out by Vellard (1959), Cei (1958, 1972), and Köhler (2000). Bufo marinus is by far a much larger species than $B$. poeppigii [although populations outside Neotropics may be of moderate size (Henle, 1985; Zug \& Zug, 1979)], attaining a snout-vent length (SVL) of $240 \mathrm{~mm}$ (Reed \& Borowsky, 1970; Duellman \& Trueb, 1986), and females are considerably larger than males (Zug \& Zug, 1979). In B.

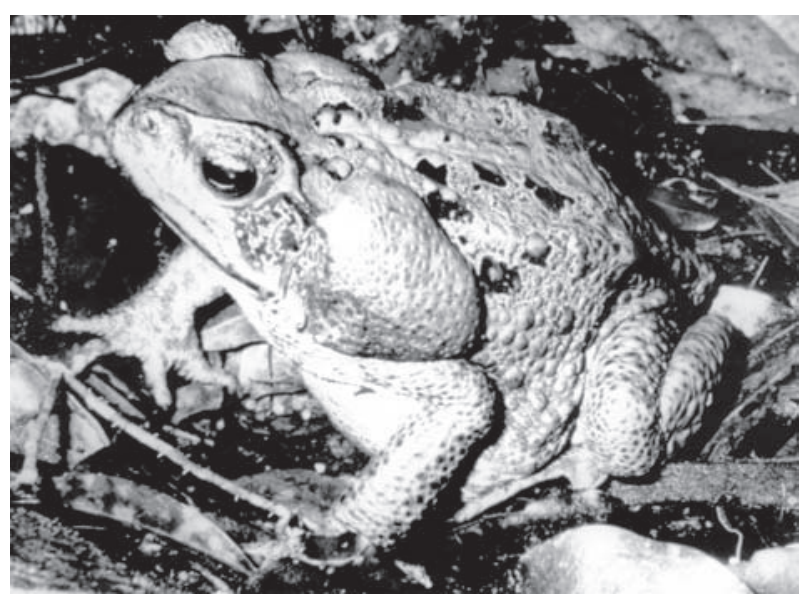

Fig. 3.- Bufo marinus (not collected) from Cuzco Amazónico, Peru (KU slide \# 10007).

Fig. 2.- Bufo marinus (ejemplar no colectado) del Cuzco Amazónico, Perú (KU diapositiva \# 10007).

poeppigii there is no such marked sexual dimorphism in size; the largest female examined (AMNH 137401 ) is $132.8 \mathrm{~mm}$ in SVL, and the largest male (one in the same lot as female USNM 193887) is $112.0 \mathrm{~mm}$ in SVL. Zug \& Zug (1979) indicated that in Panama, females of $B$. marinus reach sexual maturity at a size of $90-100 \mathrm{~mm}$. In contrast, one female of $B$. poeppigii with mature ovarian eggs (AMNH 72129) is only $63.3 \mathrm{~mm}$ in SVL. The degree of difference in skin texture between males and females of $B$. poeppigii is similar to that of the highland species $B$. spinulosus. Males always have a highly rugose skin, whereas females have a fairly smooth skin. Given the variation in B. marinus, skin texture itself is not a reliable character to distinguish the two species, unless large samples are available; when they are, it becomes obvious that the presence of heavy skin rugosity in males of $B$. poeppigii is a consistent character. The advertisement call of $B$. poeppigii differs from that of $B$. marinus; however, the calls of the two species are generally similar, and perhaps the call alone does not guarantee reproductive isolation (De la Riva et al., 1996). As was demonstrated by Blair (1972) and Bogart (1972) by means of karyotype studies, $B$. poeppigii and B. marinus are closely related species and may hybridize. Obviously, hybrid individuals can complicate even further the allocation of particular individuals to one or the other species, as was noted by Vellard (1959) for the region of Tingo María (Department of Huánuco, Peru). 


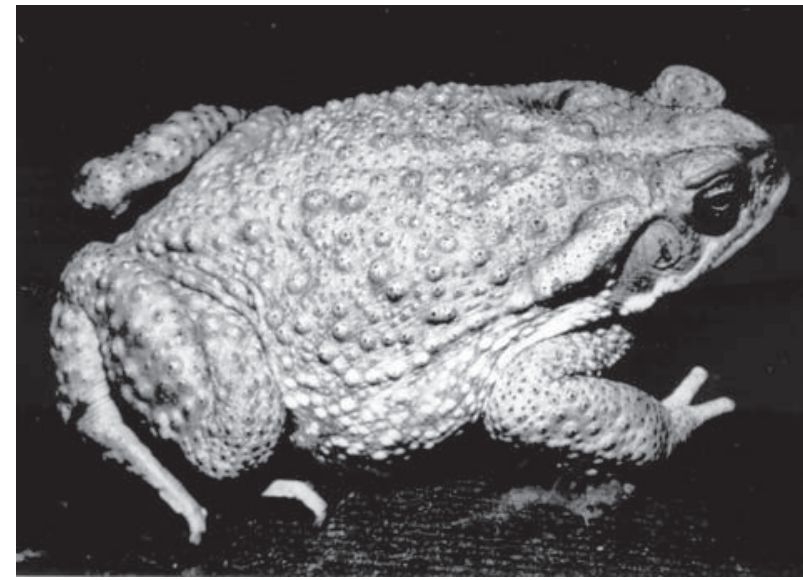

Fig. 4.- Bufo arenarum (KU 183186) from Aiquile, Bolivia (KU slide \# 6432).

Fig. 4.-Bufo arenarum (KU 183186) de Aiquile, Bolivia (KU diapositiva \# 6432).

As was pointed out by Cei $(1958,1972), B$. poeppigii is quite similar to $B$. arenarum (Figs. 1 and 4). From $B$. arenarum, B. poeppigii differs mainly by its slightly smaller size and by the shape of the parotoids. In B. arenarum, the parotoids are long and enlarged anteriorly; commonly they are in contact with the orbitotympanic crest or invest the postorbital crest, and the posterior end of the parotoid is followed by a series of smaller glands. In $B$. poeppigii the parotoids are subtriangular and (as in $B$. marinus) there is always a separate short postorbital crest (Fig. 1). Bufo arenarum and B. poeppigii do not occur sympatrically. In Bolivia, $B$. arenarum occurs from Cochabamba to Tarija departments in Chacoan lowland forests, Chacoan montane forests, inter-Andean valleys and montane forests at least to $2600 \mathrm{~m}$ (De la Riva et al., 2000).

\section{Distribution and ecology}

The distribution of $B$. poeppigii also is the subject of some controversy. Nieden (1923) said that the species occurs in Colombia and Ecuador, a logical statement upon considering $B$. andianus Cope, 1868 [type locality: "Valley of Quito and Carthagena, New Grenada" (Colombia)] as a junior synonym of $B$. poeppigii. However, Cochran \& Goin (1970) did not report B. poeppigii from Colombia and Miyata (1982) and Coloma (1991) did not report it in Ecuador, although Frost (1985:
57) gave as distribution of the species "Cloud forests of the Andean slopes of Colombia, Ecuador, Peru, and Bolivia, 800-1670 m; ...”. Almendariz (1991) included B. poeppigii in her list of Ecuadorian amphibians, and more recently, RuizCarranza et al., (1996), based on Frost's information, included the species in the list of amphibians of Colombia but they explicitly stated that it is unknown in the country. In summary, the occurrence of the species in these two countries has not been documented.

On the other hand, Vellard (1959) stated that $B$. marinus poeppigii crosses the Huancabamba Depression in northern Peru and reaches the Pacific coast from Olmos (Departament of Lambayeque) to the Ecuadorian border. However, Duellman \& Wild (1993) did not report the species (nor B. marinus) in the Huancabamba Depression and I have examined no specimens from the Pacific versant of Peru and Ecuador that are referrable to B. poeppigii. Thus, it is necessary to consider the list of localities for B. poeppigii provided by Vellard (1959: 36) with reservation. Rodríguez et al. (1993) reported $B$. poeppigii in the Peruvian departments of Huánuco, Junín, Loreto, Madre de Dios, San Martín, and Ucayali. Most Peruvian localities provided by Henle (1992) for B. marinus poeppigii refer to $B$. marinus, not to $B$. poeppigii.

Bufo poeppigii occurs at least from the region of the upper Huallaga River (Department of San Martín, Peru) to Amboró National Park and Buenavista area (Department of Santa Cruz, Bolivia), between elevations of 260-1829 m (Fig. 5). Following Henle's results, I misidentified as $B$. arenarum the first specimens of $B$. poeppigii that I collected at Villa Tunari and those from Caranda in the MNK [De la Riva, 1990: 265, and Fig. 7; to the best of my knowledge, this is the first published photograph of the species; in addition to that photograph and the one published herein, are those published by Köhler (2000: Plate I-f) and De la Riva et al. (2000: 80)]. The report by Andersson (1938) of B. spinulosus at Mojos (La Paz, Bolivia, $1600 \mathrm{~m}$ ) most probably corresponds to $B$. poeppigii (De la Riva, 1990); as stated above, males of $B$. poeppigii have a dorsal skin as rugose as that of the males of B. spinulosus, and the degree of sexual dimorphism in this character is similar in both species.

Bufo poeppigii reaches the lowlands in areas adjacent to the foot of the mountains, but it is not found far from the Andes. During the breeding season, males congregate at ephemeral ponds and puddles (even in the middle of villages), as well as 


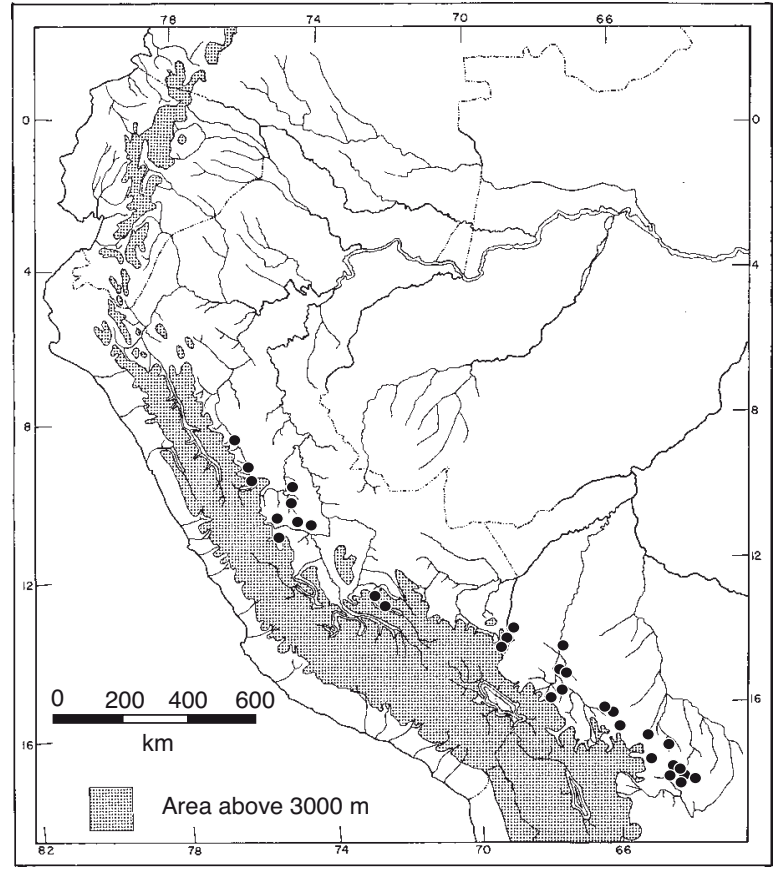

Fig. 5.- Distribution of Bufo poeppigii in Peru and Bolivia.

Fig. 5.- Distribución de Bufo poeppigii en Perú y Bolivia.

in ponds isolated in river beds. Bufo marinus typically is a lowland, anthropophyllous toad that colonizes new areas following roads and river banks and it is often found in villages and human settlements; the species seldom enters the closed rainforest. Where B. poeppigii does not occur, B. marinus seems to reach higher elevations [for example, $1600 \mathrm{~m}$ in Venezuela (Rivero, 1961)]. Generally both species occur in open habitats and reproduce in similar places but usually they are not found together. However, there are some localities at which both species occur, namely Bulo-Bulo (Department of Cochabamba, Bolivia), Puerto Linares (La Paz, Bolivia), Rurrenabaque (Beni, Bolivia) and the region of Tingo María (Huánuco, Peru). The two species might occur in the zone of the upper Tambopata River (Madre de Dios, Peru) (McDiarmid, pers. comm.).

Two specimens, one from Moyobamba (Department of San Martín, Peru) (KU 211746) and another from Misión Bomboiza (Province of Morona Santiago, Ecuador) (KU 147082), are herein tentatively considered as $B$. marinus; however, their general pattern and morphology are also coincident with $B$. poeppigii. Further research in northern Peru and southern Ecuador is needed in order to ascertain whether or not $B$. poeppigii actually occurs in these regions.

\section{Discussion}

As has been explained, the binomial Bufo poeppigii is the name traditionally linked to the smaller species of the $B$. marinus group occurring on the eastern Andean slopes of Peru and Bolivia. However, it is necessary to reiterate that because the holotype of $B$. poeppigii is a poorly-preserved juvenile whose type locality is relatively imprecise, it could actually be a juvenile $B$. marinus from a low locality in this area (B. marinus USNM 166768 , is a voucher for the occurrence of the species at low elevations in the region). If this is true, Henle's (1985) conclusion about the synonymy of the two nominal taxa was correct. If so, there is no available name for the species considered herein as $B$. poeppigii. Because there is no unequivocal solution to this problem, I recommend that the name $B$. poeppigii continue to be applied to the small species of Bufo closely related to $B$. marinus primarily inhabiting cloud forest in the central Andes.

Given that $B$. poeppigii has a distribution mostly parapatric with that of $B$. marinus, that they are sometimes barely distinguishable, and that they might hybridize, why not consider it as a mere subspecies of $B$. marinus adapted for living at higher altitudes? Bufo poeppigii is not simply a set of populations of $B$. marinus with a smaller size as a response to the environment at higher elevations (which might represent suboptimal conditions); populations of $B$. poeppigii from localities at $260 \mathrm{~m}$ are indistinguishable from those at $1800 \mathrm{~m}$, so there is no clinal variation in size. In considering $B$. poeppigii as a valid species, I adopt here the evolutionary species concept as explained by Wiley (1978) and expanded by Frost \& Hillis (1990). From this point of view, $B$. poeppigii is a single lineage with reproductive cohesion, its own evolutionary trend, and representing a homogeneous entity (in fact, easier to diagnose than $B$. marinus) uniformly distributed across a defined area. There is no known case of a widely distributed Neotropical anuran with a subspecies on the Andean slopes, a pattern that could be expected in other species if $B$. poeppigii was no more than a regional race of $B$. marinus. We still know so little about tropical amphibians that the use of subspecies should be precluded, among other reasons, 
because we could be underestimating biodiversity, and there are not objective reasons to do this (Frost \& Hillis, 1990).

Collection of natural history data and direct experience with the species in the field prove to be invaluable in order to distinguish species, particularly when no obvious morphological differences are present. In such a complex fauna as South American amphibians, much field work is needed; in many cases, conclusions obtained only from the study of preserved specimens can be misleading.

\section{AKNOWLEDGMENTS}

I thank W. E. Duellman and L. Coloma for their useful comments on the complicated subject of the taxonomic status and distribution of B. poeppigii. Apart from some anonymous reviewers, W. E. Duellman, C. Shiel, and especially J. R. Mendelson III, reviewed previous drafts of the manuscript, improving it considerably. W. R. Heyer, R. McDiarmid, and R. Reynolds helped me in many ways during my stay at the Smithsonian Institution. C. Myers, D. Frost, L. Ford, and D. Kizirian provided space and help during my visits to the AMNH. C. Dufour (MHNN) and G. Nilson (NHMG) graciously sent to me the type material under their care. M. C. Tapia and M. E. Montaño (MNK) sent me important data, and J. Simmons helped me with the photos in the dark room. The Museo de Historia Natural "Noel Kempff Mercado" and the Colección Boliviana de Fauna facilitated my field work in Bolivia. The publication of this paper has been partially funded by project REN2001-1046, Ministerio de Ciencia y Tecnología, Spain (Principal Investigator: Ignacio De la Riva).

\section{References}

Almendariz, A., 1991. Lista de vertebrados del Ecuador. Anfibios y reptiles. Politécnica, 16(3): 89165.

Andersson, L. G., 1938. Batrachians from Burma collected by Dr. R. Malaise and from Bolivia and Ecuador collected by Dr. Hamnarland. Arkiv för Zoologi, 30: 1-24.

Bertini, F. \& CEI, J. M., 1961. Seroprotein patterns in the Bufo marinus Complex. Herpetologica, 17(4): 231-238.

BLAIR, W. F., 1972. Evidence from hybridization. In: W. F. Blair (ed.). Evolution in the genus Bufo. University of Texas Press, Austin \& London: 196232.

Bogart, J. P., 1972. Karyotypes. In: W. F. Blair (ed.). Evolution in the genus Bufo. University of Texas Press, Austin \& London: 171-195.

Cadle, J. E. \& Patton, J. L., 1988. Distribution patterns of some amphibians, reptiles, and mammals of the eastern Andean slopes of southern Peru. In: W. R Heyer \& P. E. Vanzolini (eds.). Proceedings of a workshop on Neotropical Distribution Patterns. Academia Brasileira de Ciências, Rio de Janeiro: 225-244.

CEI, J. M., 1958. Remarks on the geographical distribution and phyletic trends of South American toads. The Pearce-Sellards series, 13: 1-20.

CEI, J. M., 1972. Bufo of South America. In: W. F. Blair (ed.). Evolution in the genus Bufo. University of Texas Press, Austin \& London: 81-92.

Cochran, D. \& GoIn, C. J., 1970. Frogs of Colombia. United States National Museum Bulletin, 288: 1-655.

Coloma, L. 1991. Anfibios del Ecuador: Lista de especies, ubicación altitudinal y referencias bibliográficas. Reportes técnicos Ecociencia. 46 pp.

DE LA Riva, I. 1990. Lista preliminar comentada de los anfibios de Bolivia con datos sobre su distribución. Bolletino del Museo regionale di Scienze naturali Torino, 8(1): 261-319.

De la Riva, I., Bosch, J.\& Márquez, R. 1996. The advertisement calls of two Bolivian species of toads (Anura: Bufonidae: Bufo). The Herpetological Journal, 6(2): 59-61.

De la Riva, I., Köhler, J., Lötters, S. \& Reichle, S. 2000. Ten years of research on Bolivian amphibians: updated checklist, distribution, taxonomic problems, literature, and iconography. Revista Española de Herpetología, 14: 19-164.

Duellman, W. E., 1979. The herpetofauna of Andes: patterns of distribution, origin, diferentiation and present communities. In: W. E. Duellman (ed.). The South American herpetofauna: Its origin, evolution and dispersal. Museum of Natural History, University of Kansas Monographies 7. Lawrence, Kansas: 371-459.

Duellman, W. E., 1993. Amphibian species of the world: Additions and corrections. University of Kansas Museum of Natural History Special Publications, 21: 1-372.

Duellman, W. E., 1999. Distribution patterns of Amphibians in South America. In: W. E. Duellman (ed.). Patterns of Distribution of Amphibians. A Global Perspective. The John Hopkins University Press, Baltimore: 255-328.

Duellman, W. E. \& Schulte, R. 1992. Description of a new species of Bufo from northern Peru with comments on phenetic groups of South American toads (Anura: Bufonidae). Copeia, 1992(1): 162-172.

Duellman, W. E. \& Toft, C. A., 1979. Anurans from Serranía de Sira, Amazonian Perú: Taxonomy and biogeography. Herpetologica, 35(1): 60-70.

Duellman, W. E. \& Trueb, L., 1986. Biology of the Amphibians. McGraw-Hill Inc. New York. 670 pp.

Duellman, W. E. \& Wild, E. R., 1993. Anuran amphibians from the Cordillera de Huancabamba, northern Peru: Systematics, ecology, and biogeography. 
Occasional Papers of the Museum of Natural History, The University of Kansas, 157: 1-53.

EMmONS, L. H. 1991. Observations on the herpetofauna. In: T. A. Parker \& B. Bailey (eds.). A biological assessment of the Alto Madidi region and adjacent areas of northwest Bolivia. RAP Working Papers 1, Conservation International, Washington D. C.: 74.

Frost, D. R., 1985. Amphibian species of the world. A taxonomic and geographical reference. Allen Press and the ASC. Lawrence, Kansas. 732 pp.

Frost, D. R. \& HiLlis, D. M., 1990. Species concept and practice: Herpetological applications. Herpetologica, 46(1): 87-104.

Glaw, F., Köhler, J., Hofrischter, R. \& Dubois, A., 1998. Systematik der Amphibien: Liste der rezenten Familien, Gattungen und Arten. In: R. Hofrischter (ed.). Amphibien. Naturbusch Verlag. Augsburg: 252-258.

Gorham, S. W., 1974. Checklist of world amphibians. Saint John. New Brunswick. 173 pp.

GutTman, S. I., 1972. Blood proteins. In: W. F. Blair (ed.). Evolution in the genus Bufo. University of Texas Press. Austin \& London: 265-278.

Harding, K. A., 1983. Catalogue of New World Amphibians. Pergamon Press. New York. 406 pp.

HARVEY, M. B., 1997. Reptiles and amphibians from the vicinity of El Palmar in the Andes of Chuquisaca, Bolivia. In: T. S. Schulenberg \& K. Awbrey (eds.). A rapid assessment of the humid forests of south central Chuquisaca, Bolivia. RAP Working Papers 8, Conservation International, Washington D. C.: 33$36,83-84$.

Hass, C. A., Dunski, J. F., Maxson, L. R. \& Hoogmoed, M. S., 1995. Divergent lineages within the Bufo margaritifera complex (Amphibia: Anura: Bufonidae) revealed by albumin immunology. Biotropica, 27(2): 238-249.

Henle, K., 1985. The status of Bufo poeppigii Tschudi, 1845 (Anura: Bufonidae). Studies on Neotropical Fauna and Environment, 20: 167-173.

Henle, K., 1992. Zur Amphibienfauna Perus nebst Beschreibung eines neuen Eleutherodactylus (Leptodactylidae). Bonner Zoologische Beiträge, 43(1): 79-129.

KÖHLER, J., 2000. Amphibian diversity in Bolivia: a study with special reference to montane forest regions. Bonner Zoologische Monographien, 48: 1243.

Mertens, R., 1952. Amphibien und Reptilien. In: G. Fischer (ed.). Beiträge fur Fauna Perus, Vol. III: Wissenschaftliche Bearbeitungen. Jena: 257-266.

MiYATA, K., 1982. A check list of the amphibians and reptiles of Ecuador with a bibliography of Ecuadorian herpetology. Smithsonian Herpetological Information Service, 54: 1-70.
Morales, V. R., 1995. Check list and taxonomic bibliography of the amphibians from Perú. Smithsonian Herpetological Information Service, 107: 1-20.

Müller, L. \& Hellmich, W., 1936. Wissenschaftliche Ergebnisse der Deutschen Gran Chaco-Expedition. Amphibien und Reptilien. I. Teil: Amphibia, Chelonia, Loricata. Strecker und Schröder Verlag. Stuttgart. 120 pp.

Nieden, F., 1923. Anura I. Subordo Aglossa und Phaneroglossa, Sectio 1, Arcifera. Das Tierreich, 46: $1-584$.

Reed, C. A. \& Borowsky, R., 1970. The "World's largest toad" and other herpetological specimens from southern Surinam. Studies on Fauna of Surinam \& Guyanas, 12: 159-171.

Rivero, J. A., 1961. Salientia of Venezuela. Bulletin of the Museum of Comparative Zoology, 126: 1-207.

Rodríguez, L. O., Córdova, J. H. \& Icochea, J., 1993. Lista preliminar de los anfibios del Perú. Publicaciones del Museo de Historia Natural UNMSM, (A), 45: 1-22.

Roux, J., 1907. Révision de quelques espèces de reptiles et de batraciens du Pérou décrits par Tschudi. Revue Suisse de Zoologie, 15: 293-303.

Ruiz-Carranza, P. M., Ardila-Robayo, M. C. \& LYNCH, J. 1996. Lista actualizada de la fauna de Amphibia de Colombia. Revista de la Academia Colombiana de Ciencias Exactas, Físicas y Naturales, 20(77): 365-415.

Stephens, L. \& TraYlor, M. A. 1983. Ornithological Gazetteer of Peru. Harvard University. Cambridge. $271 \mathrm{pp}$.

TsCHUDI, J. J. Von, 1845. Reptilium conspectus quae in Republica Peruana reperiuntur et pleraque vel collecta sunt in itinere. Archiv für Naturgeschichte, 11: $150-170$

Vellard, J., 1955. Répartition des batraciens dans les Andes au sud de l'équateur. Travaux de l'Institute Française d'Études Andines, 5: 141-161.

Vellard, J., 1959. Estudios sobre batracios andinos. V. El género Bufo. Memorias del Museo de Historia Natural Javier Prado, 8: 1-48.

Wiley, E. O., 1978. The evolutionary species concept reconsidered. Systematic Zoology, 27(1): 17-26.

Zug, G. R. \& Zug, P. B., 1979. The marine toad, Bufo marinus: A natural history resumé of native populations. Smithsonian Contributions to Zoology, 284: 158.

Recibido, el 16-IV-2002 Aceptado, el 2-VII-2002 Publicado, el 5-IX-2002 
Appendix I.- Specimens examined and localities.

Apéndice I.- Ejemplares examinados y localidades.

The distributional records of $B$. poeppigii not supported by voucher specimens, and those in which voucher specimens have not been examined personally by the author, but that represent plausible localities, are listed followed by the authority of the report. Museum acronyms are: KU: Natural History Museum, The University of Kansas; USNM: United States National Museum of Natural History, Smithsonian Institution; AMNH: American Museum of Natural History; MHNN: Museé d'Histoire Naturelle de Neuchâtel; NHMG: Naturhistoriska Museet, Göteborg; MNK: Museo de Historia Natural Noel Kempff Mercado (Santa Cruz, Bolivia); CET: Centro de Estudios Tropicales (Sevilla, Spain).

Bufo arenarum: ARGENTINA.- Tucumán: El Cadillal, 500 m, KU 160284-97; 18 km SSE Tafí del Valle, 1880 m, KU 160281-2; BOLIVIA.- Cochabamba: Aiquile, 2300 m, KU 183186; Cochabamba, 2650 m, KU 136191-6; Cliza, 2650 m, KU 136197.

Bufo marinus: BOLIVIA.- Beni: Confluence Río Blanco and Iténez, AMNH 78973; Guayaramerín, AMNH 78972; Río Iténez, ca. 2 km above Costa Márquez, AMNH 78970; Río Mamoré, 5 km S Guayaramerín, AMNH 78971; Rurrenabaque, USNM 280443-4, 280448; AMNH 108305; Tumi Chucua, USNM 279869-88; Cochabamba: Bulo-Bulo (personal observation); Valle de Sajta, MNK AM 314; La Paz: Puerto Linares, USNM 281017, 281019, 281028-9; San Buenaventura, USNM 280441; ECUADOR.- Guayas: 15 km NNW Guayaquil, 25 m, KU 120342-4; Morona-Santiago: 5.3 km NE Plan de Milagro, KU 202273, 1550 m; Misión Bomboiza, 840 m, KU 147082; Pastaza: Limoncocha, KU 98975-83. PERU.- No locality: MHNN 90.87 (two syntypes of Bufo molitor); Huánuco: Finca Panguana, Río Llullapichis, 200 m, KU 154903, 154906-8, 171907-13, 178995; Tingo María, 670 m, USNM 193899-900, 193904; Lambayeque: 7.5 km N Olmos, KU 196655; 11 km N Olmos, KU 196660; 12 km N Olmos, KU 196661; Loreto: Río Ampiyacu, Estirón, AMNH 114843-4; Río Curanja, Balta, 300 m, KU 196662-7; Río Napo at Río Mangua, KU 191988;
Upper Ucayali River, AMNH 5166-7; Madre de Dios: Cocha Cashu, Río Manu, 400 m, KU 154904-5, 154910-1; Cuzco Amazónico, 15 km E Puerto Maldonado, KU 194914, 2052356, 205826; Zona Reservada Tambopata-Candamo, $300 \mathrm{~m}$, USNM 332403; Pasco: Nevati Mission, ca. 300 m, USNM 166768; Piura: Río Piura in Piura, KU 219742-3; San Martín: Moyobamba, $860 \mathrm{~m}$, KU 211746; Roque, $35 \mathrm{~km} \mathrm{SE}$ Moyobamba, NHMG 457 (two syntypes of Bufo marinus andinensis); Tumbes: Matapalo, 90 m, KU 219744.

Bufo poeppigii: BOLIVIA.- Beni: Rurrenabaque, USNM 280437-40; Cochabamba: Carahuasi, 1829 m, CET A 1666-8; 6.5 km N Chipiriri, 260 m, KU 136048; Río Chipiriri, AMNH 72106-29; Villa Tunari, 300 m, MNK AM 299, 312; Bulo-Bulo (personal observation); La Paz: Alto Madidi, $270 \mathrm{~m}$, USNM 336131-3; Caranavi, 680 m, KU 183262-4, 183807; Coroico, 1750, KU 183191-261, 183803-6, 183808; Mojos, $1600 \mathrm{~m}$ (Andersson, 1938); Puerto Linares, USNM 281016, 281021-2, 281032, 281034-5, 281037; Río Beni, $20 \mathrm{~km}$ (by river) N Puerto Linares, 600 m, KU 206086; Santa Cruz: Caranda, MNK AM 10-11; Río Cheyo, Amboró National Park, CET 1627-8, MNK AM 239; Ríos Pitasana y Surutú, Amboró National Park, MNK AM 5, 13; Río Saguayo, Amboró National Park, MNK AM 109, 187, 190, 215. PERU.- Cuzco: Puente de San Miguel, Machu Picchu, ca. 1800 m, USNM 60802-3; 12 km S Quillabamba, $1010 \mathrm{~m}, \mathrm{KU}$ 173228; Huánuco: Aucuyacu, 600 m, USNM 193890 (four specimens); Serranía de Sira (Duellman \& Toft, 1979); Tingo María, 670 m, USNM 193898, 193903; Junín: Chancharia on Río Perene below Pampa Silva, ca. 5 miles above entrance of the Río Ipoki, ca. 700 m, USNM 193902 (seven specimens); Montañas de Monobamba, MHNN 90.77 (holotype of B. poeppigii); San Ramón, 800 m, KU 136094; Pasco: Cacazú (Hass et al., 1995); Tsioventini, ca. 1260 m, USNM 166757; Yaupi, 1620 m, KU 139053-75, 139432-3; Puno: Vicinity of San Juan, $5000 \mathrm{ft}$, and San Ignacio, 3000 ft, AMNH 137401-3; San Martín: Tocache Nuevo, 497 m, USNM 193887 (13 specimens). 